\title{
AN AMBIGUOUS PHENOMENON OF HYBRID WARFARE. THEORY AND POLICY PRACTICE OF GEORGIA
}

\author{
Vephkhvia GRIGALASHVILI, PhD \\ Faculty of Business-Technology, Georgian Technical University, Georgia \\ grigalashviliv@gmail.com
}

\begin{abstract}
Despite the growing actuality of hybrid warfare, modern democratic political institutions have not yet been able to formulate a generally accepted and coherent view of hybrid warfare, nor formulate one consolidated definition for this new form of warfare. Considering the fact that for modern revisionist forces, hybrid warfare is a tool for changing the existing world order and achieving their political goals, it is worth noting that international law has not yet defined the legal status of "hybrid warfare". Therefore, there is a grey area which allows revisionist forces free rein, according to the current state of affairs, because they are not bound by appropriate legal obligations. In view of the above, understanding the political-strategic characteristics and concepts of hybrid warfare are essential for developing hybrid defence strategies and other mechanisms to protect against hybrid threats. This is also critical in terms of maintaining the world order, in a sustainable way, and for developing effective national security policies. Given the current state of affairs, this article analyses the key characteristics and political strategies related to the phenomenon of hybrid warfare, considers the approaches taken by individual states (including Georgia) and reflects upon scientific opinion. Then, based on the induction method and conceptual analysis, the latter part of this article proposes a political and strategic conceptual framework of hybrid warfare, in which the tools/methods and means of conducting hybrid warfare are explored, along with the groupings, objectives and actors involved in hybrid warfare.
\end{abstract}

Keywords: Hybrid Warfare Concept, Russian Hybrid Warfare Strategy, Georgian Hybrid Defence Policy.

\section{Introduction}

Strategic approaches to security policy have undergone significant changes in recent history. As D. Barno notes, modern wars are increasingly taking an amorphous form (Barno, 2014), and this phenomenon becomes increasingly unclear, as the modern concept of hybrid warfare develops.

Despite the growing actuality of hybrid warfare, in the context of global and national security, modern democratic political institutions have not yet been able to incorporate this new form of warfare into one consolidated definition. Furthermore, they have not yet been able to 
formulate a generally accepted conceptual view of hybrid warfare. The homogeneous definition of hybrid warfare is further complicated by a diversity of terminology. For instance, some refer to this phenomenon as "hybrid warfare", while others use the term "hybrid military action" or "hybrid conflict", all within a similar context.

The term "hybrid threat" is most commonly used when attempting to define hybrid warfare. However, in general, this approach is not recommended because the word 'threat' itself implies something that might happen (Oxford English Dictionary). Therefore, something can be perceived as a threat, when in actuality it is likely, or very likely, to happen. Consequently, the term "hybrid threat" is so narrow that it cannot cover the entire spectrum of probabilities and importance, in the context of hybrid warfare. Moreover, the use of the word "warfare" instead of the word "threat" similarly does not provide sufficient information.

Some of the most prominent organisations have been unable to formulate and agree upon a final definition for hybrid warfare. These organisations include the Department of Defence of the United Kingdom, the U.S. Department of Defense, and other research institutions, such as the International Institute for Strategic Studies, the Royal Institute for Joint Services in Defence and Security Studies, and the Centre for Strategic and International Studies.

Two organisations that have made an attempt to institutionalise a conceptual framework for the hybrid warfare phenomenon are NATO and the EU. However, their conceptual framework is so comprehensive that it loses all of its practical value. Another example is that of the Munich Security Conference (a non-profit foundation), which in 2015 sought to develop a pan-European conceptual framework for hybrid warfare (i.e., a combination of conventional and nonconventional means) (Munich Security Conference, 2015). However, this conceptual framework again created ambiguity and uncertainty, which was primarily due to the multiplicity of the factors associated with this new phenomenon (diplomacy, information warfare and propaganda, support for local disturbances, irregular troops, special forces, regular armed forces, economic warfare and cyberattacks), and in particular the endless combinations associated with these factors.

In this context, it can be argued that every attempt to define a conceptual framework for hybrid warfare makes a significant contribution to the development of the overall knowledge and understanding of hybrid warfare. At the same time, however, this has further compounded and complicated the understanding of the increasingly complex phenomenon of hybrid warfare. 


\section{A Conceptual Framework for Hybrid Warfare}

The ideas that underpin hybrid warfare have been derived from the analysis of conflicts in the recent past. However, as the renowned expert Keir Giles has argued, this type of warfare has existed for centuries, and only some aspects are new additions. These additions are primarily due to the widespread adoption of Internet based media and the adaptation of these centuries' old methods into modern technological security strategies. Moreover, the impact of propaganda and misinformation can be further enhanced by its skilful dissemination, so as to subtly influence and shape the many shades of public opinion, both at home and abroad.

It is difficult to determine the exact origin of the term "hybrid warfare". However, according to most sources, this term was first mentioned in its current form by William J. Nemeth in his 2002 paper, where he theorised that hybrid warfare would be the dominant form of warfare into the future. In his work, Nemeth used the first and second Chechen wars as an example, and it was here that the concept of hybrid warfare was born in his mind. Firstly, Nemeth described Chechen society as hybrid-like, because of their more or less communal/tribal organization. According to Nemeth, Chechen society was in a hybrid state as a result of the blending of the past and the present, and so the structure of society was based on the traditional family clan system (Nemeth, 2002.pp.3-29).

This hybrid-like structure of Chechen society allowed Chechens to mobilise for war, and subsequently actively support the war, through family ties. A new hybrid form of war therefore emerged from this hybrid society, which combined both regular and irregular forces in a very flexible and effective manner. Although the article does not provide a clear definition of hybrid warfare, we can understand Nemeth's thesis. In particular, Nemeth considers hybrid warfare to be the practice of hybrid societies that have evolved in a way that is different to the modern state based system. In his opinion, hybrid warfare is a modern form of guerrilla warfare, which has become more effective thanks to modern technologies and modern methods of mobilisation (Nemeth, 2002, pp.3-29).

Based on Nemeth's work and the later events of the Second Lebanon War in 2006, F. G. Hoffman developed the most well-known definition of hybrid warfare (threats). According to Hoffman, hybrid warfare simultaneously includes a number of methods, including conventional capabilities, irregular tactics and formations (Hoffman, 2007a. p.14). In Hoffmann's analysis of various forms of modern conflicts, hybrid threats are defined as follows: threats are hybrid when 
any enemy simultaneously uses the relevant combination of conventional weapons, irregular tactics, terrorism and criminal behaviour, in the domain of the conflict, to achieve their political goals. Hoffman also recognises that the problem with the definition of hybrid threat is that it focuses on a combination of different tactics related to violence and war (excluding criminal acts), but does not include other non-violent actions (Hoffman, 2014b). Hoffman also emphasises the fact that the hybrid warfare is characterised by widespread terrorism and various forms of crime.

One criticism of the definition developed by Nemeth is to do with his characterisation of non-state actors, to which Hoffmann proposes to use the term hybrid warfare, in which hybrid wars are waged by both state and non-state actors (Hoffman, 2007a).

After the 2006 Lebanese war, the debate about hybrid warfare temporarily ceased and the debate instead focussed on a new generation of conventional warfare, with asymmetric elements. Subsequently, U.S. defence experts argued over whether the 2008 Russian-Georgian war was a hybrid conflict, and two approaches emerged: the U.S. Air Force viewed the conflict as a hybrid war, while other institutions used the term "hybrid threat" (possibly because of political restraint) to reflect the dialectics of the conflict (Government Accountability Office, 2010. p.140).

Although there is still no official definition of the term hybrid warfare that has been formulated by the U.S. Department of Defense, there are unofficial definitions of this term in the military concepts of the U.S. armed forces. For example, the United States Joint Forces Command explains hybrid warfare as a conflict conducted by a state and/or non-state actors using various methods, including conventional capabilities, irregular tactics and criminal offences (Government Accountability Office, 2010. p.18).

Since 2010, NATO has been providing an overall explanation of hybrid threats and presenting their multidimensional characteristics. Hybrid threats are those that are characterised by parallel capabilities - the ability to convert conventional and non-conventional means from one form to another, with the overall effect of achieving the desired goals. According to M. Miklauci, the concept of NATO's actions against hybrid warfare supports the approach of a coordinated use of the capabilities of allies (diplomatic, economic, intelligence, etc.) (Miklauci, 2011).

The United Kingdom also pays great attention to hybrid threats, albeit in a different form. The Joint Defense Doctrine states that hybrid threats arise when state and non-state actors apply different methods of warfare simultaneously, while using the latest conventional weapons, 
irregular tactics, terrorism, and destructive criminal actions to destabilise the existing order (Ministry of Defence, 2009).

Attitudes towards the phenomenon of hybrid warfare have changed significantly since the events in Ukraine in 2014 (including the annexation of Crimea). Russia's actions in 2014 were a wake-up call for Western societies to resume debate (e.g., the final report of the 2015 Munich Security Conference) on Europe's future security, and the fight against these new types of threat.

In April 2017, following the signing of a Memorandum of Understanding between NATO and the EU, a new international hub called the Hybrid CoE (Hybrid Centre of Excellence) was established in Finland, for the purposes of understanding and defending against hybrid threats, and in particular for assessing the methods and actions directed against the vulnerabilities and weaknesses of targeted enemies (Hybrid CoE, 2018).

According to Treverton et al (2018), hybrid threats in the 21 st century involves the complementary and simultaneous use of various instruments and tools. Propaganda is a key instrument, and long known, however the ubiquitous adoption of media technology gives it new means. It is also possible to list: fake news, influence over domestic media outlets, strategic leaks, funding of organisations, political parties, organised protest movements, oligarchs, economic leverage, proxies, religious organisations, parliamentary organisations and in particular the synchronisation of these tools. Clearly, the coordinated use of these tools is a powerful means to achieve the political objectives of an adversary, especially when used simultaneously, they combine to greater effect. In addition to the complementarity just described, the other defining feature of hybrid warfare is the strategic use of these instruments of power, both horizontally and vertically. The meaning of this is that the adversary will target the vulnerabilities of their target state, for instance political divisions, social media, energy dependence, as well as proximity and access. The targeting of such vulnerabilities is also dynamic, in the sense that they are employed to achieve specific objectives, which may, or may not change, as the campaign proceeds (Treverton et al, 2018. pp.46-67).

In his 2017 report, the NATO Secretary General indicated that hybrid warfare includes both military and non-military action, covert and open tactics, ranging from misinformation and propaganda to the use of irregular armed groups or regular forces. Hybrid warfare erases the boundaries between war and peace. Modern hybrid threats include complex cyberattacks, 
economic and political pressure, and the exploitation of enemy vulnerabilities (NATO Secretary General Annual Report, 2017).

The 2018 NATO Secretary General's report, which also discusses hybrid warfare, states that in a century of hybrid warfare, countries may not be aware that they have been hit by a hybrid attack until they have suffered serious damage. Hybrid methods of warfare, such as propaganda, fraud, sabotage and other non-military tactics, have long been used by state and non-state actors to destabilise an enemy (NATO Secretary General Annual Aeport, 2018).

To clarify the dialectics and structure of hybrid warfare, it is important to consider the broad view proposed by D. Kilcullen that hybrid warfare is an event that establishes a link between armed and unarmed forces, military and non-military activities, governmental and nongovernmental actors, as well as domestic and international factors, both with and without violence (Kilcullen, 2009).

In addition to military force, hybrid warfare includes various instruments of influence, including economic pressure, religious indoctrination, humane actions calculated to sway allegiance, intelligence service actions, coordinating the formation and activities of criminal groups, as well as sabotage and misinformation.

To augment the above, A. Jacobs and G. S. Lasconjarias offer a rather general, but at the same time universal explanation of hybrid warfare, which is eminently plausible. According to their theory, hybrid warfare is to do with a violent form of conflict involving governmental and non-governmental actors, who have unlimited means of conventional and non-conventional influence on the battlefield, or a particular territory. The authors argue that all traditional, irregular, and field-tested forms of armed conflict have gradually merged and coalesced to effect a large destructive power within the strategic framework in which hybrid warfare has become a driving force, for the planned and desired outcomes (Jacobs et la, 2015. p.2-3). This, according to A. Deep, is achieved by using asymmetric methods and tactics, and is thoughtfully synchronised on the multidimensional battlefield (Deep, 2015. p.1).

T. Mcculloh and R. Johnson also introduce a variety of cultural aspects to the theory of hybrid warfare. They describe the theory of hybrid warfare as a form of war in which, based upon an optimally designed structure of the armed forces and in specific cultural contexts, all available methods and means - both conventional and non-conventional are applied, and aimed at achieving synergetic effects against an enemy acting in a conventional way (Mcculloh et la, 2013. p.1). 
Based on an analysis of the experience gained during the wars in Vietnam and Afghanistan, J. J. McCuen is developing the idea of a broad interpretation of hybrid conflict as a full spectrum military action. According to McCuen, hybrid conflicts represent the full spectrum of military operations in both the physical and conceptual dimensions. The first is the fight against the armed enemy, and the second is a broader struggle to secure the support of the local population in the theatre of war; at the same time, the struggle for general support in the domestic and international arenas. Moreover, in order to consolidate and stabilise the theatre of war, security, necessary utilities, local government, defensive structures and important elements of the economy must be restored immediately (McCuen, 2008).

The approach of the American researcher R. Glenn to the phenomenon of hybrid conflict is equally interesting. Glenn was one of the first to emphasise the growing importance of nonmilitary tools for the success in the modern era of warfare. Glenn provides an in-depth analysis of the Israeli-Lebanese conflict of 2006, and in addition to military force, shows that both the state and private actors pursuing the interests of the state, use both economic and diplomatic means, as well as criminal and terrorist methods, in a hybrid conflict (Glenn, 2009).

The definitions and characterisations of hybrid warfare, as discussed above, are both enlightening and illuminating, and yet there is still an overall lack of coherence. This, as previously mentioned, argues for a more precise strategic and dynamic definition of hybrid warfare. The use of the word 'dynamic' so as to stress that as the phenomenon of hybrid warfare continues to develop, its definition must also necessarily evolve.

Nevertheless, before formulating such a consolidated definition, we can at least posit that a "hybrid war" should comprise of the following characteristics:

A. An adversary who engages in a form of low-intensity conflict (political and military confrontation between competing states, or groups, at a lower level than conventional warfare, albeit beyond the normal peaceful competition between states (Military Operations in Low Intensity Conflict, FM 100-20/AFP 3-20, 1990); because their goal is for the conflict to remain below the brink of a full-scale war, although we must remember that a relatively small-scale conventional war is part of the concept of hybrid warfare.

B. An unconventional, complex and flexible adversary, which may be a state (for example, Russia's role in the Ukrainian conflict), or a non-state group/organisation (for example, Hezbollah, or the so-called Islamic State) (Fleming, 2011. pp. 2-4). 
C. An adversary who always uses a combination of conventional and non-conventional methods.

D. A hybrid adversary who is characterised by flexibility and quick adaptability, whose methods involve the use of modern high-tech weapons and associated means (Deep, 2015).

E. An adversary who makes widespread use of the media and propaganda to disrupt the political landscape and recruit supporters. Moreover, to make false accusations and portray an "alternative truth" (e.g. misleading propaganda by Russia against Georgia and Ukraine).

\section{Russian Hybrid Warfare Strategy}

The military doctrine of the Russian Federation, in 2010, identified new issues related to the conduct of war and the resolution of unforeseen problems, but these issues were more about the characteristics of modern conflict than about the armed forces themselves. The doctrine addresses the issue of the integrated use of military and non-military targets, along with the requisite resources. The doctrine emphasises the importance of the informational space, as a new dimension. The doctrine assumes that information warfare allows for the achievement of political goals, without the use of military force or alternatively creates conditions for the use of such force (Military Doctrine of the Russian Federation, 2010).

A subsequent military doctrine of the Russian Federation, in 2014, contains provisions on asymmetric methods of action; such as actions to eliminate the advantage of the adversary, allowing for the participation of irregular military units and private military contractors in the conflict. Considerable emphasis is placed on the cultivation of political forces and social movements that are managed and financed from outside the country (Военная доктрина Российской Федерации, 2014).

These changes in doctrine are well illustrated by the opinions of Russian strategy experts, expressed in their articles on warfare.

A retired general of the Russian army, M. Gareev, uses the term "future war" instead of "hybrid war". Gareev stresses the importance of technological development and the growing importance of the information war; propaganda can more effectively demoralise the enemy, as well as destabilise the situation, in order to contribute to the success of the aggressor (Gareev, 1998). 
Gerasimov V., the Chief of the General Staff of the Russian Federation, wrote in February 2013 that he envisions a gradual erosion of the line between war and peace in the $21^{\text {st }}$ century, just as the line between the actions of uniformed personnel and undercover personnel disappears. Currently, countries do not declare war, but simply start with unknown and usually unpredictable events. He refers to the experience of the 'colour revolutions' in North Africa and the Middle East and argues that a stable state can be reduced to chaos in just a few months, or face a humanitarian disaster, or civil war, in just a few days, as a result of armed conflict and unconventional intervention. Gerasimov points out that the importance of non-military tools is changing, and that in many cases its effectiveness exceeds that of conventional armed forces. He stresses the value of an increased role for special operations against the internal opposition, which aims to create a continuous front that supports information operations throughout a hostile state. Moreover, he advocates the deceptive use of regular armed forces in supposed peacekeeping operations, at a certain phase in a conflict, for the purposes of achieving ultimate success (Герасимов, 2013a).

Gerasimov V. uses the words "future war", but suggests coining the term "a new generation war", or "non-linear war", in which different rules will apply. Small groups will start hostilities in peacetime and then escalate to more aggressive actions, taking the situation to the brink of fullscale war. In this "new generation war", there will be remote clashes between highly manoeuvrable groups of hybrid units, as well as precise and targeted attacks on military and civilian infrastructure, aimed at defeating the enemy's armed forces and economic power. The primary focus of V. Gerasimov's paper is a so-called "central-network war" and "non-linearity", and these ideas became the basis for the reforms of the Russian Armed Forces, planned for the 2008-2020 timeframe (Герасимов, 2013b).

With reference to other recent Russian publications, one of particular interest is that of Colonel-General A. Kartapolov, of the Russian Army. In his opinion, it has become necessary to develop unconventional methods and tactics to defeat the enemy, especially when they are superior in terms of technological and combat power. Also, it is worth noting that A. Kartapolov not only supports the use of hybrid methods to carry out covert aggression, as in the case of Ukraine, but also when conducting larger scale combat operations (Andrey, 2015).

Another text of particular interest is allegedly by the head of V. Putin's administration -V. Surkov, published under the pseudonym of N. Dubovitsky. In Dubovitsky's 2014 essay, "Without Heaven", he speaks of a future war that would be comprehensive, waged in any legal or illegal 
way, that would target all aspects of life, but at the same time would be a war that would be 'under the radar' and sufficiently covert so as to be barely perceptible (Дубовицкий, 2014).

Other experts believe that hybrid warfare is a military strategy that is a mixture of conventional and non-conventional warfare, along with cyber warfare. Furthermore, according to the existing state of affairs, combat operations are combined with clandestine anti-state actions, with responsibility for such actions carefully transferred to proxies. Consequently, the aggressor seeks to avoid accountability to the international community and thus, as far as possible, avoid retaliation within the framework of international law (NATO review magazine, 2014).

The theory of "rebellious war", developed by the Russian strategist E. Messner, is regarded as a prototype for hybrid warfare.

According to E. Messner's concept, a state can officially avoid participating in a war. Nevertheless, a state can undertake irregular actions (such as diversion, terror, guerrilla activities and uprisings) that will give the conflict the appearance of a civil war, and internal chaos. Moreover, he posits that the line between regular armed forces and the civilian population is gradually disappearing, as are the boundaries of the theatre of military actions. It then becomes difficult to distinguish between the objective realities of the parties involved in the struggle. The level of aggression may also vary widely, so that it is not so easy to distinguish between the legal and illegal means of armed struggle. Furthermore, with regular combat forces slowly losing their monopoly on warfare, this inevitably leads to unethical warfare. Messner notes that active diplomacy in a rebellious war plays a big role and compares active diplomacy to a form of war in itself. He also characterises diplomacy as a white glove policy that uses various forms of intimidation to impose compliance with one's own objective(s) or to achieve an agreement on important issues (Месснер, 2005. pp. 70-110).

In addition to the above, Messner pays special attention to information activities that can be aimed at causing dissatisfaction among the general public and confrontation within the political elite. Also, information activities that attempt to undermine a state's reputation, as well as foment political isolation or negatively impact on the opinion of the international community (Месснер, 2005. pp. 232-246).

Finally, one observation that distinguishes Russian authors is that they do not write about how to protect their own state from hybrid threats, but about how to succeed with these methods. 


\section{Conceptualisation of Hybrid Warfare in Georgia's National Security Framework}

Georgian political institutions have been documenting and discussing the use of hybrid warfare tactics against Georgia, since 2017. However, it should be noted that official explanations by the leading political figures in the country suggest that hybrid war has been waged against Georgia since the early 1990s, and that belligerent forces continue to use these methods (President Margvelashvili, 2018).

Given that Georgia's political elite are well aware of the above, the country has still not been able to address the institutional shortcomings identified by S. Neil McFarlane in Georgia's National Security Concept (i.e. neglecting important hybrid threats, misunderstanding the significance of threats and having unrealistic expectations, in the face of real contradictory evidence) (MacFarlane, 2012). The National Security Concept document explains national security values and interests, develops a vision for the country's safe development, identifies threats, risks and challenges facing the state, and defines the main thrusts of national security policy. Therefore, it is a critical document in terms of Georgia's national security, and especially in the context of hybrid threats and hybrid warfare.

With the above situation in mind, and in order to better address the conceptualisation of hybrid warfare, Georgia is considering both reviewing the conceptual national security document at the state level ("Strategic Defence Review of Georgia 2017-2020"), which deals with hybrid threats, as well as analysing the official approaches taken by individual state bodies, including the (unclassified) parliamentary reports of the State Security Service for 2017 and 2018, which most clearly elucidate the goals, objectives and tactics of hybrid warfare.

At this point it is useful to provide further detail about the Georgian Strategic Defence Review of 2017-2020 (SDR, 2017) It was developed using a threat-based methodology, as Georgia still faces potential/ongoing aggression from the Russian Federation, and should therefore be prepared to address any escalation of the situation, as well as counter hybrid challenges. However, it is important to note that the Georgian Strategic Defence Review document does not attempt to define hybrid tactics of warfare, and does not provide a clear understanding of what hybrid warfare methods mean. However, it is noteworthy that the text of the document does contain important provisions for the understanding of the political aspects of hybrid warfare, from a Western perspective: 
A) In the section about the Georgian national environment, it alludes to the Kremlin's use of economic leverage and "soft power tools", which are to the detriment of the Georgia's national interests. In addition, this section describes the dangers associated with Russia's "creeping" occupation, unilateral recognition of the occupied territories within Georgia and the placement of Russia's military infrastructure there. Clearly, this increases the probability and risk of provocation, along with renewed military aggression;

B) In the Planning section, it is assumed that the Russian Federation has the propensity to ignore the sovereignty of its neighbouring states. In particular by neglecting the norms of international law, using open military aggression and hybrid methods of warfare, as well as perpetuating a serious security situation; Russia will continue its efforts to weaken Georgia's national unity and civil accord, increase division within Georgian society and destabilise the tolerance that exists between ethnic and religious groups. The Kremlin will pay particular attention to strengthening soft power elements under its influence, in order to weaken Georgian state institutions, strengthen pro-Russian social and political groups and discredit the Western paradigm for foreign policy; The Russian Federation continues to use its political and economic leverage to limit international political support for Georgia and limit opportunities for Georgia to deepen its international cooperation aimed at strengthening the country's defence capabilities;

C) In the context of the assessment of the situation in Georgia's region, it is stated that one of the strategic goals of the Russian Federation is to obtain and maintain control over the region's energy resources and their distribution systems. Furthermore, in light of future threats from the Russian Federation and other actors, ensuring energy security and maintaining its transit function will remain a challenge for Georgia.

Georgia's Foreign Policy Strategy document for 2019-2022 also refers to hybrid threats. The document makes the assertion that the Russian Federation and its military forces are increasingly using hybrid warfare methods to achieve its foreign policy goals, which seek to overturn well-established Western values, by subtly pushing its own agenda in all strata of society, in particular countries (FPS, 2019). It should be noted that this document presumes that Russia, on the one hand, will use conventional military force, and on the other hand, hybrid warfare, for its foreign policy agenda. The purpose of these actions being to roll back, as far as possible, Western leaning values in society. But here, as in other documents, it is not explained what Georgia's government means in terms of hybrid warfare methods. 
On the related subject of soft power, more clarity is provided by the Foreign Policy Strategy 2019-2022 document, as compared to the Strategic Defence Review document. The 2019-2022 Foreign Policy Strategy document makes the assertion that together with cyber security, soft power is increasingly important in international relations, and the document defines the means of projecting soft power as political, economic, informational and technological. Also, in the context of information warfare, we should consider the following extract from the document: "The speed of the dissemination of information has increased, along with the role of social media. Consequently, the use of propaganda and misinformation techniques, designed to achieve the goals of specific countries and institutions, requires a timely adaptability and response" (Akubardia, 2017).

In view of the above, it would be logical to assume that the methods of hybrid warfare set out in the Foreign Policy Strategy, which primarily focuses on the threat of Western values being rolled back, should coincide with the goals associated with the use of "soft power". However, this is not explicitly stated in the strategy, and the methods of hybrid warfare are separate from the methods of so-called "soft power".

An Agency Level document, the Communication Strategy for 2017-2020, approved by the Georgian Ministry of Defence, duplicates the concept of hybrid methods, as per the Strategic Defence Document. However, cyberattacks, and information warfare, are detailed separately in this strategy. Additionally, although the so-called "soft power" policy is mentioned as a concern, its concept is not detailed or explained (CS, 2017).

Another Agency Level document, the Defence Minister's Directives 2018, clearly conveys the actuality of hybrid warfare methods being used against Georgia: "Russia's use of hybrid methods of warfare, especially propaganda, poses a significant challenge to the country". In order to implement these directives and overcome these challenges, the Ministry of Defence took a multi-pronged approach. Firstly, to implement improved strategic communications, involving the communication of a shared, coordinated vision to all state agencies, on the importance of state defence. Secondly, to provide national and international training of personnel, so as to increase overall defence capabilities, as well as to improve intelligence capabilities (including the development of a doctrinal framework for training, so as to more effectively respond to hybrid actions). Finally, to develop the combat capabilities of the Special Forces, ensuring their readiness 
for hybrid warfare methods, as well as their flexibility in terms of asymmetric action and special operations (MD, 2018).

The Defence Minister's Directives, 2019, refer to the complex hybrid security challenges facing Georgia and the requirement to rapidly adopt the lessons from the international experience of hybrid warfare, in terms of hybrid countermeasures and defence strategies. Therefore, in 2019, special attention will be given to the preparedness of the Georgian armed forces, so that they can more effectively operate in a hybrid environment. To this end, 2019 has been declared the "Year of Cyber Security", and priority will be given to the development of cyber security capabilities. Thus, it can be concluded that cyber security is seen by the minister as the primary solution to the hybrid challenge (MD, 2019).

The State Security Service offers another perspective on the hybrid threats facing Georgia, in its recent annual parliamentary reports. These reports are not included in the list of conceptual documents at the National Level, so this imposes some limitations. Nevertheless, the State Security Service is a government agency working in the area of national security, and is legally required to be involved in the planning and coordination of national security policy.

In the State Security Service's 2017 report, the primary objectives of adversarial foreign security services in Georgia were as follows: "To cultivate anti-Western sentiment in Georgian society; to undermine Georgia's image as a reliable partner at the international level; to create distrust, uncertainty, despair and nihilism in the society; to create pockets of ethnic and religious destabilisation in order to foment disintegration processes in the country and to polarise Georgian society". If we compare this text with the later 2018 report, we find that the situation is even more difficult in this regard, as is the domain pertaining to hybrid warfare and tactical actions. The report states that the analysis of information obtained as a result of counter-intelligence activities revealed key security challenges facing the country, including encroachment affecting territorial integrity, destabilisation, the creation of separate hotspots of disorder and attempts to polarise society, as well as the threats to economic expansion and attempts to negatively affect the foreign exchange rate. The fact that the list of key security challenges has increased over the past year, along with threats to territorial integrity and sovereignty is a serious challenge in the context of Georgia's national interests (GSSSr,2017).

According to the 2018 report of the State Security Service, adversarial countries interested in strengthening their influence in Georgia actively used hybrid warfare methods to achieve their 
goals. With regard to the objectives of foreign intelligence services using these methods, the report lists them as follows: Instigating confrontation between different ethnic and religious groups living in Georgia, inciting anti-Western sentiment, actions calculated to cause the deterioration of bilateral relations between Georgia and the countries of the region, and relationships with strategic partners (a novelty in this report), undermining Georgia's image as a democratic and stable country, gaining economic leverage, contributing to constant internal political tension and promoting uncertainty and nihilism in society. The report also notes that destructive political forces and social groups, as well as media and social media, were actively used by stakeholders during these hybrid warfare activities. As for the hybrid methods of warfare, they are listed as the following: A disinformation campaign characterised by false news, distortion of facts and falsification of history, aimed at polarising the population, spreading false beliefs and fears, influences on important processes through the manipulation of public opinion. A separate chapter in the report is devoted to the use of cyber tools during cyberattacks and cyber-intelligence operations carried out by foreign intelligence agencies, as well as coordinated hacking activity against government and critical infrastructure sites (GSSSr-2018).

The overall analysis of the documents reviewed, shows that different agencies (whether it be the Ministry of Defence, the Ministry of Foreign Affairs or the State Security Service) provide some sort of classification of hybrid threats to the country, and yet in some cases refer to them as hybrid methods, and sometimes even "soft power". However, in this case, the problem is not only in terminology. The essence of the problem is that the assessment of this phenomenon is not based on a unified state approach, set out in the national security concept documents, at the National Level.

\section{Conclusion}

For the purposes of this article, we have analysed the concepts underpinning various political and scientific approaches to the phenomenon of hybrid warfare, which allows us to formulate a comprehensive view of hybrid warfare from a laconic and political-strategic point of view - Hybrid warfare is the joint and synchronised use, by state or non-state actors, of all available tools/methods, including conventional or non-conventional, legal or illegal methods and instruments, against predetermined weaknesses of a target country, to achieve the desired political goals. 


\section{Acknowledgments}

The author would like to thank Dr. Genadi Iashvili and Dr. Shota Dogonadze, professors at Georgian Technical University, for their assistance and guidance in the research process.

The study was funded by the Shota Rustaveli National Science Foundation (Grant No. PhD_F-17-123, Project Name: Problems of Georgian National Defense Management and Solutions).

\section{References}

1. GEORGIAN FOREIGN POLICY STRATEGY 2019-2022 (2019)

2. AKUBARDIA, T. (2017). Soft Power or Hybrid Warfare? How does the Georgian Government Clarify These Two Terms within the Context of National Security and the Corresponding Treat on the Level of National Security Fields Official Documentation, Research Paper, Strategic Analysis Center, 2018

3. ANDREY, V. (2015). Kartapolov's Lessons of Military Conflicts and Prospects for the Development of Resources and Methods of Conducting Them. Direct and Indirect Actions in Contemporary International Conflicts," Journal of the Academy of Military Science

4. BARNO, D. (2014). The Shadow Wars of the 21st Century, "War on the Rocks"

5. DEEP, A. (2015). Hybrid War: Old Concept, New Techniques, "Small Wars Journal"

6. FLEMING, B. (2011). Hybrid threat concept: contemporary war, military planning and the advent of unrestricted operational art." Us Army CGSC, DRP

7. GAREEV, M. (1998). „If War Comes Tomorrow? The Contours of Future Armed Conflict"،, Translated by Yakov Vladimirovich Fomenko. Routledge, Abingdon

8. GEORGIAN STATE SECURITY SERVICE ANNUAL PARLIAMENTARY REPORT GSSSr (2017)

9. GEORGIAN STATE SECURITY SERVICE ANNUAL PARLIAMENTARY REPORT GSSSr (2018)

10. GEORGIAN STRATEGIC DEFENCE REVIEW 2017-2020 (2017)

11. GLENN, R. (2009). ,Thoughts on Hybrid Conflict“", Small Wars Journal

12. GOVERNMENT ACCOUNTABILITY OFFICE. (2010). National Defence: Hybrid Warfare. GAO-10-1036R, Washington, D.C.: U.S. Government Accountability Office 
13. HOFFMAN, F. G. (2007a). Conflict in the 21st Century: The Rise of Hybrid Wars, Potomac Institute for Policy Studies Arlington, Virginia

14. HOFFMAN, F.G. (2014b). On Not-So-New Warfare: Political Warfare vs Hybrid Threats

15. HYBRID CoE. (2018). 'Hybrid Threats', The European Centre of Excellence for Countering Hybrid Threats

16. JACOBS, A,. LASCONJARIAS, G. (2015). NATO's Hybrid Flanks: Handling Unconventional Warfare in the South and East, Research Paper, NDC Rome, No.112

17. KILCULLEN, D. (2009). The accidental guerrilla: fighting small wars in the midst of a big one, Oxford University Press, Oxford

18. MACFARLANE, S. N. (2012). Georgia: National Security Concept versus National Security, Chatham House, London

19. MCCUEN, J.J. (2008). „Hybrid Wars“, Academic journal article Military Review, Vol. 88, No. 2

20. MCCULLOH, T., JOHNSON, R. (2013). Hybrid Warfare, JSOU Report 13-4, Joint Special Operations University

21. MIKLAUCI, M. (2011). NATO Countering the Hybrid Threat

22. MINISTRY OF DEFENCE OF GEORGIA. Communication Strategy 2017-2020 - (2017)

23. MINISTRY OF DEFENCE OF GEORGIA. Minister`s Directives - MD (2019)

24. MINISTRY OF DEFENCE OF GEORGIA. Minister`s Directives -MD (2018)

25. MINISTRY OF DEFENCE. (2009). Security and Stabilisations: The Military Contribution, Joint Doctrine Publication 3-40, JDP 3-40

26. MUNICH SECURITY CONFERENCE. (2015). Munich Security Report

27. NATO REVIEW MAGAZINE. (2014). Deterring hybrid warfare: a chance for NATO and the EU to work together?

28. NATO SECRETARY GENERAL'S ANNUAL REPORT (2017)

29. NATO SECRETARY GENERAL'S ANNUAL REPORT (2018)

30. NEMETH, W. J. (2002). Future War and Chechnya: A Case for Hybrid Warfare, Thesis, Naval Postgraduate School, Monterey, California.

31. OXFORD ENGLISH DICTIONARY, 'threat', [Online], Available at: http://www.oed.com/view/Entry/201152?rskey=zLMoGh\&result=1\#eid [accessed on 25.07.2019] 
32. PRESIDENT OF GEORGIA WEBSITE, President Margvelashvili Calls on the Government to Urgently Establish a Structure Replacing the National Security Council. (2018). https://www.president.gov.ge/geo/pressamsakhuri/siakhleebi/prezidentmamtavrobas-sascrafod-da-intensiur-rejim.aspx (accessed on 08.01.2019)

33. THE MILITARY DOCTRINE OF THE RUSSIAN FEDERATION (2010)

34. TreVErtON, G., Thvedt, A., Alicia, R. Chen, KLee K., and McCue, M. (2018). Addressing Hybrid Threats, Swedish Defence University and the authors

35. US ARMY, Military Operations in Low Intensity Conflict, FM 100-20/AFP 3-20. (1990)

36. В ВОЕННАЯ ДОКТРИНА РОССИЙСКОЙ ФЕДЕРАЦИИ (2014)

37. ГЕРАСИМОВ, В. (2013a). Роль Генерального штаба в организации обороны страны в соответствии с новым Положением о Генеральном штабе, утверждённым Президентом Российской Федерации, Official Speech

38. ГЕРАСИМОВ, В. (2013b). Новые Вызовы Требуют Переосмыслить Формы И Способы Ведения Боевых Действий, Российской Федерации, «Военнопромышленный курьер» No. 8 (476)

39. ДУБОВИЦКИЙ, Н. (2014). „Без неба“, Русский пионер

40. MEССНЕР, Е.Э. (2005). Хочешь Мира, Победи Мятежойну!, Москва, Военный Университет Русский Путь 